\title{
Effect of irrigation regime on yield and water productivity of maize (Zea mays) in the Lake Tana basin, North West Ethiopia
}

Amare Tsige genet ( $\sim$ amaretsigegenet@gmail.com )

Amhara Regional Agricultural Research Institute https://orcid.org/0000-0002-7448-3362

dires Tewabe

Amhara Regional Agricultural Research Institute

atklte abebe

Amhara Regional Agricultural Research Institute

alebachew enyew

Amhara Regional Agricultural Research Institute

mulugeta worku

Amhara Regional Agricultural Research Institute

\section{Research}

Keywords: Irrigation interval, irrigation Scheduling, crop water requirement Koga and Ribb

Posted Date: August 4th, 2021

DOl: https://doi.org/10.21203/rs.3.rs-744982/v1

License: (9) This work is licensed under a Creative Commons Attribution 4.0 International License. Read Full License

Version of Record: A version of this preprint was published at Turkish Journal of Agriculture - Food Science and Technology on March 1st, 2022. See the published version at https://doi.org/10.24925/turjaf.v10i2.100-105.3982. 


\section{Abstract \\ Background}

Proper scheduling gave water to the crop at the right time in the right quantity to optimize production and minimize adverse environmental impact. Therefore, the objective of this study is to quantify the effects of irrigation regimes on yield and yield components of Maize in the Lake Tana basin during 2016-2018.

\section{Methods}

CROPWAT 8.0 model was used to determine the crop water requirement. Almost all parameters were adopted the default value of CROPWAT 8.0. Field data including; field capacity (FC), permanent wilting point (PWP), initial soil moisture depletion (\%), available water holding capacity ( $\mathrm{mm} / \mathrm{meter})$, infiltration rates $(\mathrm{mm} /$ day), and local climate data were determined in the study area. The treatments were arranged in factorial combinations with five irrigation depths $(50,75,100,125$ and $150 \%$ of ETc) and two irrigation intervals (14 and 21 days) laid out in a randomized complete block design with three replications.

\section{Results}

The result was analyzed using SAS 9 software and significant treatment means separated using least significant difference at $5 \%$. The result showed that the interaction of irrigation depth and irrigation frequency has no significant effect on the average grain yield and water use efficiency of maize. At koga, the highest grain yield $\left(7.3 \mathrm{t} \mathrm{ha}^{-1}\right)$ and water use efficiency $\left(0.9 \mathrm{~kg} \mathrm{~m}^{-3}\right)$ obtained from $100 \%$ ETc. while, at Ribb the highest grain yield $\left(10.97 \mathrm{t} \mathrm{ha}^{-1}\right)$ and water use efficiency $\left(1.9 \mathrm{~kg} \mathrm{~m}^{-3}\right)$ obtained from 21 days irrigation interval.

\section{Conclusion}

Therefore, for Koga and similar agro ecologies maize can irrigated with $562 \mathrm{~mm}$ net irrigation depth and 21-day irrigation interval and at Rib and similar agro ecologies maize can irrigated with $446.8 \mathrm{~mm}$ net irrigation depth and 21- days irrigation interval.

\section{Background}

Water demand increases globally more than the rate of population increases (UN 2018). Besides, expansion of irrigated agriculture, change in consumption pattern and climate change aggravate the condition (Ercin et al. 2014). However, most farmers who live in developing country cultivate crops using flood, border and furrow irrigation techniques that results in lose up to $50 \%$ water through deep percolation and tail water loss (Tewabe et al. 2020). 
To meet food demand by 2050, sub-Saharan Africa maize output must increase up to four fold (Hein et al. 2019). Introducing appropriate water management is pertinent to provide sufficient food for the rapid population growth.

Ethiopia produces 9492770.8 tons in 2,367,797.4 hectares in 2019 (CSA, 2019). The current national average productivity of farmers' is $4 \mathrm{t} \mathrm{ha}^{-1}$ while yields up to $12 \mathrm{t} \mathrm{ha}^{-1}$ recorded on research plots (Hein and Martin, 2019). Timely management of plant pests, weeds, fertilizers and proper water application are essential during the production period of maize. As a thumb rule application of over irrigation water to the crop increase leaching of nutrients, reduce grain and biomass yield which results in a reduction of water productivity (Eneyewe et al. 2020). Besides, delivering appropriate water for crops can improve nutrient availability, aeration and water productivity (Tewabe et al. 2020). CROPWAT software model is a computer program used for irrigation planning and management developed by FAO and; is widely used to estimate reference evapotranspiration (ET0) and crop evapotranspiration (ETc) (Abdalla et al., 2010). It allows the development of recommendations for improved irrigation practices, the planning of irrigation schedules under varying water supply conditions, and the assessment of production under rainfed conditions or deficit irrigation (Clarke et al., 2001). Implementing sound irrigation water management practices is essential. Therefore the objective of this study was to quantify the effects of optimum irrigation regime on yield and water use efficiency of Maize in the Lake Tana basin.

\section{Materials And Methods}

\section{Description of the study area}

The field trial conducted for two year during the dry season of 2016/17 and 2017/18 in the Lake Tana basin, North West Ethiopia. Koga irrigation scheme is located in Mecha district at $37^{\circ} 7^{\prime} 29.72^{\prime \prime}$ Easting and $11^{\circ} 20^{\prime} 57.85^{\prime \prime}$ Northing and at an altitude of $1953 \mathrm{~m}$ a.s.I. The average annual rainfall of the area is about $1343 \mathrm{~mm}$. The mean maximum and minimum temperatures are $26.8 \mathrm{OC}$ and $9.7 \mathrm{OC}$ respectively. Rib irrigation site is located in Fogera district at $37^{\circ} 25^{\prime}$ to $37^{\circ} 58^{\prime}$ Easting and $11^{\circ} 44^{\prime}$ to $12^{\circ} 03^{\prime}$ Northing and an altitude of $1794 \mathrm{~m}$ a.s.I Figure 1. It receives $1480 \mathrm{~mm}$ mean annual rainfall. The mean daily maximum and minimum temperature of the study area was $30^{\circ} \mathrm{C}$ and $11.5^{\circ} \mathrm{C}$. The area is characterized as mild altitude agroecology. The basin weather data, crop parameters, soil physical and chemical properties and others describe in Table 1.

Table 1.facts and figures of experimental input 
Ribb

Koga

\section{Soil physical property}

Soil type

Soil texture

drainage

Field Capacity (\%w/w)

Permanent Wilting Point (\%w/w)

Infiltration rate $(\mathrm{mm} /$ day)

Soil rooting depth $(\mathrm{cm})$

Initial soil moisture depilation (\%)

Soil chemical property

Available Phosphorous by Olsen methods (ppm)

Nitrogen by Micro-Kjeldahl method (\%)

Cation Exchange Capacity by ammonium acetate method $(\mathrm{cmol} / \mathrm{kg})$

$\mathrm{PH}\left(1: 2.5 \mathrm{H}_{2} \mathrm{O}\right)$

Irrigation water

Electrical conductivity $\left(\mu \mathrm{Scm}^{-1}\right)$

$\mathrm{PH}\left(1: 2.5 \mathrm{H}_{2} \mathrm{O}\right)$

Sodium absorption ratio (SAR)

Total Dissolved Solvent(mg/l)
Fluvisols

Nitisols

Silty clay

Moderately well drained

59.2

21

30

600

100

36.71

6.12

0.003

0.21

33

1.9

6.7

4.6

Well drained

32

18

40

90

100

161

124.9

8.2

8.17

0.51

0.18

188

\section{Crop water requirement and irrigation scheduling}

All calculation procedures used in CROPWAT 8.0 based on the two FAO publications No. 56 and No. 33 . Then the generated crop water and irrigation requirements values show in Table $2 \mathrm{a} \& \mathrm{~b}$. Besides dependable rainfall, (FAO/AGLW formula) method was used for the estimation of effective rainfall.

Table 2: Crop water and irrigation requirements of maize a) in Koga and b) in Ribb

a) 


\begin{tabular}{|llllllll|}
\hline Month & Decade & Stage & $\begin{array}{l}\text { Kc } \\
\text { coeff }\end{array}$ & $\begin{array}{l}\text { ETc } \\
(\mathrm{mm} / \text { day })\end{array}$ & $\begin{array}{l}\text { ETc } \\
(\mathrm{mm} / \mathrm{dec})\end{array}$ & $\begin{array}{l}\text { Eff rain } \\
(\mathrm{mm} / \mathrm{dec})\end{array}$ & $\begin{array}{l}\text { Irr. Req. } \\
(\mathrm{mm} / \mathrm{dec})\end{array}$ \\
\hline Dec & 2 & Init & 0.3 & 0.99 & 1 & 0 & 1 \\
\hline Dec & 3 & Init & 0.3 & 1.01 & 11.1 & 0 & 11.1 \\
\hline Jan & 1 & Deve & 0.31 & 1.06 & 10.6 & 0 & 10.6 \\
\hline Jan & 2 & Deve & 0.51 & 1.79 & 17.9 & 0 & 17.9 \\
\hline Jan & 3 & Deve & 0.81 & 3.01 & 33.1 & 0.1 & 33 \\
\hline Feb & 1 & Deve & 1.1 & 4.37 & 43.7 & 1 & 42.7 \\
\hline Feb & 2 & Mid & 1.29 & 5.37 & 53.7 & 1.4 & 52.3 \\
\hline Feb & 3 & Mid & 1.29 & 5.56 & 44.5 & 1.7 & 42.8 \\
\hline Mar & 1 & Mid & 1.29 & 5.73 & 57.3 & 1.9 & 55.4 \\
\hline Mar & 2 & Mid & 1.29 & 5.9 & 59 & 2.2 & 56.8 \\
\hline Mar & 3 & Late & 1.21 & 5.66 & 62.3 & 2.8 & 59.5 \\
\hline Apr & 1 & Late & 0.9 & 4.3 & 43 & 1.3 & 41.7 \\
\hline Apr & 2 & Late & 0.58 & 2.86 & 28.6 & 0.8 & 27.8 \\
\hline Apr & 3 & Late & 0.38 & 1.84 & 5.5 & 2.9 & 0.7 \\
\hline Total & & & & & 471.3 & 16.1 & 453.3 \\
\hline
\end{tabular}

b) 


\begin{tabular}{|llllllll|}
\hline Month & Decade & Stage & $\begin{array}{l}\text { Kc } \\
\text { coeff }\end{array}$ & $\begin{array}{l}\text { ETc } \\
(\mathrm{mm} / \text { day })\end{array}$ & $\begin{array}{l}\text { ETc } \\
(\mathrm{mm} / \mathrm{dec})\end{array}$ & $\begin{array}{l}\text { Eff rain } \\
(\mathrm{mm} / \mathrm{dec})\end{array}$ & $\begin{array}{l}\text { Irr. Req. } \\
(\mathrm{mm} / \mathrm{dec})\end{array}$ \\
\hline Dec & 2 & Init & 0.3 & 0.93 & 0.9 & 0 & 0.9 \\
\hline Dec & 3 & Init & 0.3 & 0.94 & 10.3 & 0 & 10.3 \\
\hline Jan & 1 & Deve & 0.31 & 0.96 & 9.6 & 0 & 9.6 \\
\hline Jan & 2 & Deve & 0.49 & 1.53 & 15.3 & 0 & 15.3 \\
\hline Jan & 3 & Deve & 0.75 & 2.43 & 26.8 & 0 & 26.8 \\
\hline Feb & 1 & Deve & 1.01 & 3.4 & 34 & 0 & 34 \\
\hline Feb & 2 & Mid & 1.17 & 4.07 & 40.7 & 0 & 40.7 \\
\hline Feb & 3 & Mid & 1.17 & 4.21 & 33.6 & 0 & 33.6 \\
\hline Mar & 1 & Mid & 1.17 & 4.33 & 43.3 & 0 & 43.3 \\
\hline Mar & 2 & Mid & 1.17 & 4.45 & 44.5 & 0 & 44.5 \\
\hline Mar & 3 & Late & 1.1 & 4.26 & 46.8 & 0.1 & 46.7 \\
\hline Apr & 1 & Late & 0.83 & 3.25 & 32.5 & 1.8 & 30.8 \\
\hline Apr & 2 & Late & 0.56 & 2.21 & 22.1 & 2.6 & 19.5 \\
\hline Apr & 3 & Late & 0.38 & 1.51 & 4.5 & 1.2 & 2.6 \\
\hline Total & & & & & 365 & 5.7 & 358.6 \\
\hline
\end{tabular}

\section{Experimental setup}

The on-farm trial was conducted with ten different treatments as shown in Table 3. Two irrigation intervals i.e. 14 and 21 days and five irrigation depths (50, 75.100,125 and 150\% ETc) of variable depths at four growth stages selected based on CROPWAT 8.0. Besides, we used 70 percent field application for the trial. Thus, the following treatments were set and evaluated for verification of the CROPWAT prediction with field experimentation.

Table 3. Treatment combination 


\begin{tabular}{|lllcl|}
\hline Treatment & Frequency(day) & Total net irrigation depth(mm) & Ribb \\
\hline 1 & \multicolumn{3}{|c|}{ Koga } \\
\hline 2 & 14 & 307 & 277 \\
\hline 3 & 14 & 435 & 373 \\
\hline 4 & 14 & 562 & 469 \\
\hline 5 & 14 & 690 & 566 \\
\hline 6 & 14 & 818 & 662 \\
\hline 7 & 21 & 267 & 276 \\
\hline 8 & 21 & 368 & 361 \\
\hline 9 & 21 & 469 & 447 \\
\hline 10 & 21 & 570 & 532 \\
\hline
\end{tabular}

The test crop maize a variety of BH-545 planted on $3 \mathrm{~m}$ by $6 \mathrm{~m}$ plot size, Spacing between treatments and block was 1 and $2 \mathrm{~m}$ respectively. The test crop maize had $0.75 \mathrm{~m}$ and $0.3 \mathrm{~m}$ spacing between row and plants respectively. $\mathrm{P}_{2} \mathrm{O}_{5}$ fertilizer applied at a rate of $92 \mathrm{~kg} \mathrm{ha}^{-1}$ at planting and $46 \mathrm{~kg} \mathrm{~N} \mathrm{ha}^{-1}$ applied half at planting and the remaining half at 45 days after planting.

The water application method was surface irrigation technique that applies through furrow and a siphon hose was used for measuring the amount of water we applied using a constant head. The flow rate was estimated using the volumetric method. . This has done by collecting water in a tank of known volume. $\mathrm{Q}=\mathrm{V} / \mathrm{t}$ where, $\mathrm{V}=$ volume of container $\left(\mathrm{m}^{3}\right), \mathrm{t}=$ time taken $(\mathrm{hr})$ and $\mathrm{Q}=$ discharge of irrigation water $\left(\mathrm{m}^{3} \mathrm{hr}^{-1}\right)$ for both experimental sites Gore \& Banning, (2017). Water use efficiency calculated as the ratio of crop yield over applied irrigation water using Micro soft excel Oweis and Zhang, (1998).

\section{Data Analysis}

The collected data subjected to analysis of variance (ANOVA) using SAS version 9. Mean comparison was done by using least significant difference test at $5 \%$ probability level.

\section{Results And Discussion}

\section{Dynamics of soil volumetric moisture contents}


Changes in the volumetric soil water content of the irrigation regime treatments during the first year experimental periods shown in Figure 2. Although the experiment conducted during the dry season, there was a rainfall (31 $\mathrm{mm}$ at Ribb and $42 \mathrm{~mm}$ at Koga) during middle stage of the crop both years, leading to increase soil moisture content of the entire treatments. Even though both 14 and 21-day irrigation interval received the same rainfall, irrigation depths of 21-day interval is below FC due to less irrigation volume as compared to 14-day irrigation interval.

\section{Effect of irrigation regime on grain yield, yield component and water use efficiency}

Most parameters showed no significant difference for the interaction of irrigation interval and irrigation depth at $(P<0.05)$.

\section{Grain yield}

Effect of variable irrigation regime on yield is presented in table $4 \mathrm{a}$, irrigation depth alone significant $(P<0.05)$ in Koga. The maximum $\left(7.3 \mathrm{tha}^{-1}\right)$ grain yield was scored at $100 \% \mathrm{ETc}$. this implies application of optimum irrigation regime increased the grain yield over the deficit and excess irrigation regime. This is in close agrement with Ekubay TG, (2020) who report the maximum grain yield (7.3 t ha-1) achieved in $100 \%$ ETc in northern Ethiopia.

At Ribb, irrigation interval showed significant difference and the maximum $\left(10.97 \mathrm{t} \mathrm{ha}^{-1}\right)$ grain yield was scored at 21 day irrigation interval and the minimum $\left(9.97 \mathrm{tha}^{-1}\right)$ at 14 day irrigation interval as described in Table 4b. Maximum yield response to 21-day irrigation interval might be high water holding capacity of the soil and manageable volumetric soil moisture content during the experimental season as shown in Figure 1a. Besides $75 \%$ ETc gives maximum yield $\left(10.88 \mathrm{tha}^{-1}\right)$ as compared to full irrigation. This might be the occurrence of rainfall during middle stage of the crop, lead to increase soil moisture content of the deficit treatments. The finding is in close agreement to (Demelash $\mathrm{K}$ and Ranamukhaarachchi SL,2004), Ekubay TG,( 2020), Libing S et al, (2019),who report irrigating sufficient water during the reproductive period of maize increase the grain yield.

The grain yield production at Koga irrigation scheme is low as compared to Ribb. This might be due to poor soil fertility and acidification at Koga and good nutrient content at Ribb as described in Table 1. Maize is sensitive to soil acidity and its suitable pH ranges from 5.8 to 7, while at Koga, it was about 4.6 that are below the critical level. Besides, the soil organic matter and available phosphorus was very low based on (Clements and McGowen, 1994) category'.

\section{Green cob number}

Application of optimum irrigation regime increased the green cob number over the deficit and excess irrigation regime plot as shown in Table 4 a\&b. Irrigation interval showed significant difference $(P<0.05)$ in Koga ,the maximum 50148 and the minimum 44481 green cob number (approximately 1 cob per plant) was scored at 21 and 14 day irrigation interval respectively. The finding is in close agrement with 
Tesfaye et al. (2018); BH-545 gives one cob number per plant in Koga irrigation scheme. Despite the nonsignificance response of irrigation regime to cob number in Ribb, the maximum 47527-cob number scored at 21 - day irrigation interval. The finding is in close agrement with Tesfaye et al. (2018); BH-545 gives one cob number per plant in Koga irrigation scheme.

\section{Cob length and cob diameter}

The maximum $14 \mathrm{~cm}$ cob length and $3.9 \mathrm{~cm}$ cob diameter scored at 21- day irrigation interval in Koga. Similarly, the maximum $17.5 \mathrm{~cm}$ cob length and $4.96 \mathrm{~cm}$ cob diameter scored at 21- day irrigation interval in Ribb. The result is in close agreement to (Tesfaye et al. 2018) who reported the mean average cob length $15.9 \mathrm{~cm}$ and cob diameter $5.1 \mathrm{~cm}$.

\section{Water use efficiency}

Interaction effect between irrigation interval and depth showed a non-significant $(P<0.05)$ in both locations. Increasing the water depth from 50 to $150 \%$ ETc resulted in a decrease of water productivity from 2.7 to $1.1 \mathrm{~kg} \mathrm{~m}-3$ in Ribb and 1.4 to $0.6 \mathrm{~kg} \mathrm{~m}-3$ in Koga. By reducing frequency of irrigation from 14 to 21 days water productivity increased from 1.6 to $1.9 \mathrm{~kg} \mathrm{~m}-3$ in Ribb and 1.2 to $1.4 \mathrm{~kg} \mathrm{~m}-3$ in Koga. Compared with optimum irrigation regime, the deficit irrigation treatments saved significant depth of water with a minimum yield loss. This is in line with the finding of Ekubay TG, (2020), Libing S et al, (2019) and Enyew et al,(2020) who reported that when irrigation water becomes a limiting factor, yield losses due to reduced soil moisture could be compensated for by water use efficiency.

Table 4; combined mean of yield and yield component a) inKoga and b) in Ribb irrigation scheme a) 


\begin{tabular}{|lllllll|}
\hline & & Gy & Gcn & CL & CD & WUE \\
\hline D & 1 & 6.2 & 44630 & 13.6 & 3.9 & 1.4 \\
\hline & 2 & 5.6 & 47315 & 14 & 3.8 & 0.9 \\
& 3 & 7.3 & 49537 & 13.7 & 3.9 & 0.9 \\
\hline & 4 & 6.9 & 48148 & 13.3 & 3.9 & 0.7 \\
\hline F & 5 & 7.1 & 46944 & 14 & 3.9 & 0.6 \\
\hline & 1 & 6.6 & 44481.5 & 13.5 & 3.9 & 1.2 \\
\hline Lsd(5\%) & D & 0.01 & 0.44 & 0.14 & 0.12 & 0.001 \\
\hline & F & 0.86 & 0.001 & 0.008 & 0.66 & 0.13 \\
\hline & F*D & 0.91 & 0.58 & 0.047 & 0.35 & 0.95 \\
\hline CV & & 19.6 & 13.5 & 5.7 & 3.6 & 19.1 \\
\hline
\end{tabular}

b)

\begin{tabular}{|c|c|c|c|c|c|c|c|}
\hline & & Gy & Gcn & CL & CD & WUE & Note- F- irrigation water \\
\hline \multirow[t]{5}{*}{ D } & 1 & 10.49 & 44912 & 16.9 & 4.92 & 2.7 & \multirow{5}{*}{$\begin{array}{l}\text { depth(mm), Gcn-Green cob number } \\
\text { (no/ha), Gy-Grain yield(t ha-1), CL- } \\
\text { Cob length (cm) CD- Cob diameter } \\
(\mathrm{cm}) \text {, and WUE- water use efficiency } \\
(\mathrm{kg} \mathrm{m}-3),\end{array}$} \\
\hline & 2 & 10.88 & 45328 & 17.58 & 4.8 & 2.1 & \\
\hline & 3 & 10.34 & 47448 & 17.1 & 4.9 & 1.6 & \\
\hline & 4 & 10.57 & 45787 & 16.6 & 4.95 & 1.3 & \\
\hline & 5 & 10.1 & 47447 & 17.5 & 4.96 & 1.1 & \\
\hline \multirow[t]{2}{*}{$\mathrm{F}$} & 1 & 9.97 & 44858 & 16.8 & 4.9 & 1.6 & \multirow{2}{*}{$\begin{array}{l}\text { Conclusion And } \\
\text { Recommendations }\end{array}$} \\
\hline & 2 & 10.97 & 47527 & 17.5 & 4.92 & 1.9 & \\
\hline \multirow[t]{3}{*}{ Lsd (5\%) } & D & 0.87 & 0.8 & 0.09 & 0.018 & 0.001 & \multirow{4}{*}{$\begin{array}{l}\text { The result of current study revealed } \\
\text { that the effect of irrigation regime } \\
\text { was not significant on grain yield, cob } \\
\text { number, cob length, and cob diameter } \\
\text { and water use efficiency. In koga the } \\
\text { maximum green cob number } 50148\end{array}$} \\
\hline & $\mathrm{F}$ & 0.04 & 0.12 & 0.004 & 0.57 & 0.0001 & \\
\hline & $F^{*} \mathrm{D}$ & 0.3 & 0.19 & 0.04 & 0.11 & 0.2 & \\
\hline CV & & 18.1 & 14.4 & 5.3 & 2.7 & 19.8 & \\
\hline
\end{tabular}

and grain, yield 7.3 t ha-1 was found with 21-day irrigation interval. In case of Ribb 21 day, irrigation interval gives 47527 green cob numbers, $10.97 \mathrm{t}$ ha-1 grain yield. Moreover, the maximum water use efficiency $(2.7 \mathrm{~kg} \mathrm{~m}-3)$ in Ribb and $1.4 \mathrm{~kg} \mathrm{~m}-3$ 
in Koga achieved at $50 \%$ ETc. The net irrigation water requirement found to be $447 \mathrm{~mm}$ for Ribb and $562 \mathrm{~mm}$ for Koga throughout the growing season. Therefore, $100 \%$ ETc and 21 days irrigation interval is recommended for Koga and similar agro ecology. For Ribb and similar agro ecology, 75\% ETc and 21 days irrigation interval is recommended.

\section{Declarations}

Acknowledgment

The author sincerely thanks to $\mathrm{mr}$. Zewdu, Alebachewe and all Adet agriculture research staffs

\section{Acknowledgement}

The Amhara Agricultural Research Institute (ARARI) is gratefully acknowledged for fnancing this research. We deeply appreciate and acknowledge Adet Agriculture research staff for their assistance in implementing the fieldwork.

Authors' contributions:, DT conceptualized this study, AT,AA,DT and AE collects necessary data, AT analyzed, interpreted the data, and wrote the manuscript. All authors read and approved the final manuscript.

Funding: This study received no external funding.

Availability of data and materials: can access from the corresponding author upon request.

Ethics approval and consent to participate: Not applicable.

Consent for publication: Not applicable.

Competing interests: The authors declare no competing interests.

\section{References}

1. Abdalla N, Zhang X, Ishag A, Gamareldawla (2010) Estimating reference evapotranspiration using CROPWAT model at Guixi Jiangxi Province. State Key Laboratory of Hydrology and Water Resources and Hydraulic Engineering, Hohai University, China, vol

2. Alebachew, Enyew, Dires Tewabe \& Amare Tsige | (2020). Determining the irrigation regime of watermelon at Koga and Rib irrigation schemes in Amhara Region, Ethiopia, Cogent Food \& Agriculture, 6:1, 1730108. https://doi.org/10.1080/23311932.2020.1730108

3. Ashiber Haile Tefera (2017) Determination of optimum irrigation scheduling and water use effciency for maize production in north west Ethiopia. Environmental science. Journal of natural science research. 559722514

4. Clarke D, Smith M, El-Askari K (2001) CropWat for Windows: user guide. IHE 
5. Clements B, McGowen I (1994) Strategic fertilizer use on pastures. NSW Agriculture. Agnote Reg. 4/57, Orange, NSW

6. CSA,(2019). Central statistical agency of Ethiopia survey report. www.csa.gov.et

7. Demelash kefale, Ranamukhaarachchi SL (2004) Response of maize variety to drought stress at different phenological stages in Ethiopia. Trop.Sci.2004,44,44-49

8. Ekubay tesfay gebreigziabher (2020) Effect of deficit irrigation on yield and water use effciency of maize at selekleka district,Ethiopia. Journal of Nepal agriculture research council. vol.6127 - 135 march 2020.ISSN 2392-4535.DOI https://doi.org/10.3126/inarc.v6io.28124

9. Ercin AE, Hoekstra AY (2014) Water footprint scenarios for 2050: A global analysis. Environ Int $64: 71-82$

10. FAO (2020) Land and water, Database and Software.online. http://www.fao.org/landwater/databases-and-software/cropwat/en/. Access September 30,2020

11. Gore JA, Banning J (2017) Discharge measurements and stream flow analysis. In Methods in Stream Ecology, Volume 1 (Third Edition) (pp. 49-70)

12. Hein ten Berge, Hijbeek R, van Loon MP, Rurinda J, Tesfaye K,.Zingore S, Craufurd P, van Heerwaarden J, Brentrup F, Schröder JJ, Boogaard HL, de Groot HLE, van Ittersum MK (2019) Maize crop nutrient input requirements for food security in sub-Saharan Africa.

https://doi.org/10.1016/j.gfs.2019.02.001. https://www.sciencedirect.com/

13. Kebede S, Travi Y, Alemayehu T, Marc V (2006) Water balance of Lake Tana and its sensitivity to fluctuations in rainfall, Blue Nile basin, Ethiopia. J. Hydrol. 2006, 316, 233-247

14. Libing, Song, Jiming Jin and Jianqiang he (2019) Effect of sever water stress on maize growth process in the field. Sustainability 2019,11,5086; doi:10.3390/su11185086.

15. Oweis T, Zhang H,(1998). Water use efficiency : Index for optimizing supplement irrigation of wheat in water scarce areas.zeitschrift fur bewasserungswirtschaft 33(2);321 - 36

16. SMEC IP,(2007). Hydrological study of the tana-beles sub-basins. Part 1

17. Tesfaye Feyisa T, Amare, Alemayehu M (eds) (2018) Proceedings of the 2 nd'and 3rd'Annual Regional Conferences on Completed Research Activities on Agricultural Water Management, January 22 to February 1, 2013 and October27-to-November2, 2014, Amhara Agricultural Research Institute (ARARI), Bahir Dar, Ethiopia.page 13-43and 88-102

18. Tewabe D, Abebe A, Enyew A, Tsige A (2020) Determination of bed width on raised bed irrigation technique of wheat at Koga and Rib irrigation projects, North West, Ethiopia. Cogent Food Agriculture 6:1712767. https://doi.org/10.1080/23311932.2020.1712767

19. UN (2018) SDG 6 Synthesis Report. Online. https://www.unwater.org/water-facts/scarcity/. Access september30, 2020

\section{Figures}




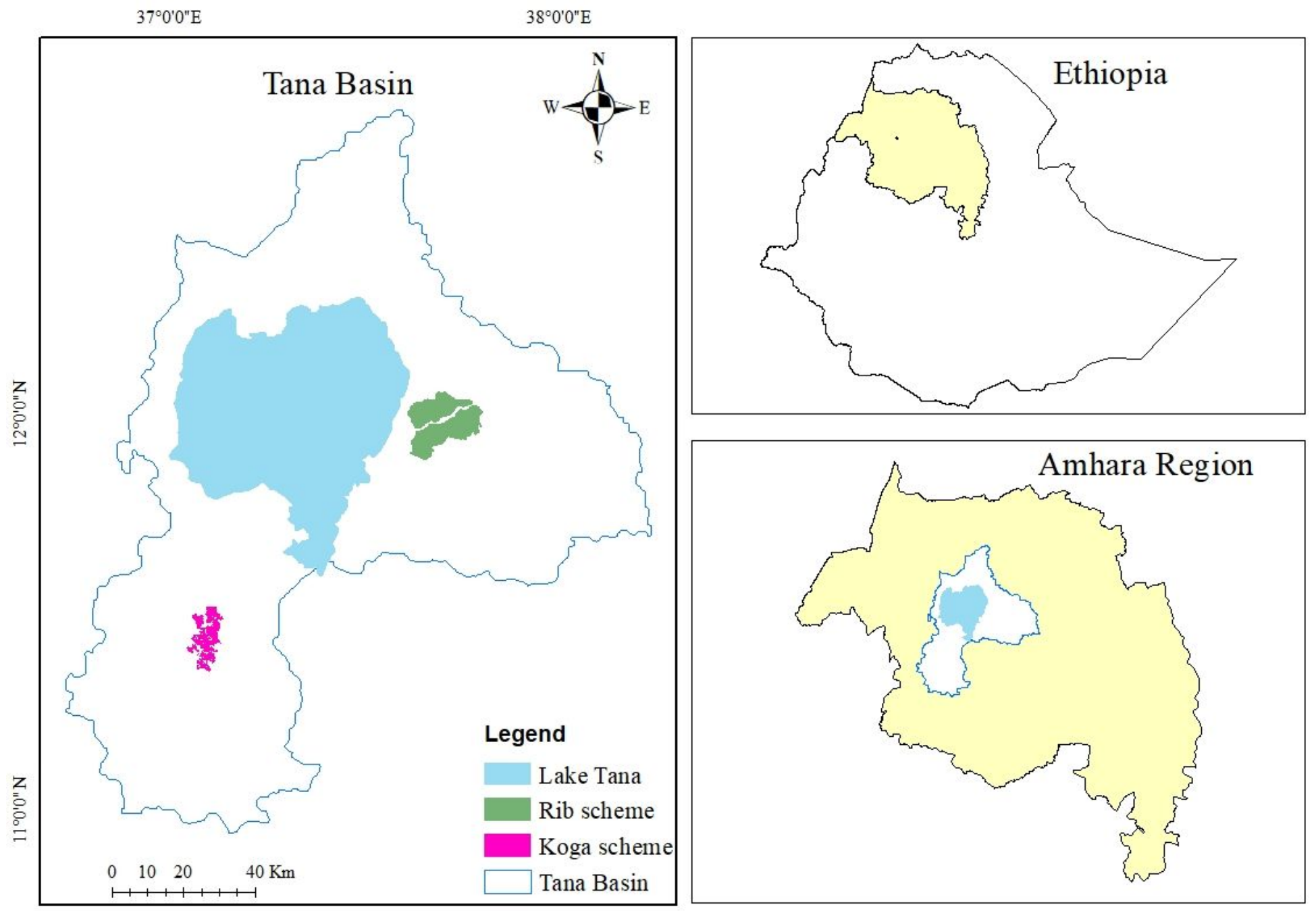

Figure 1

Site description of the study area 
a)

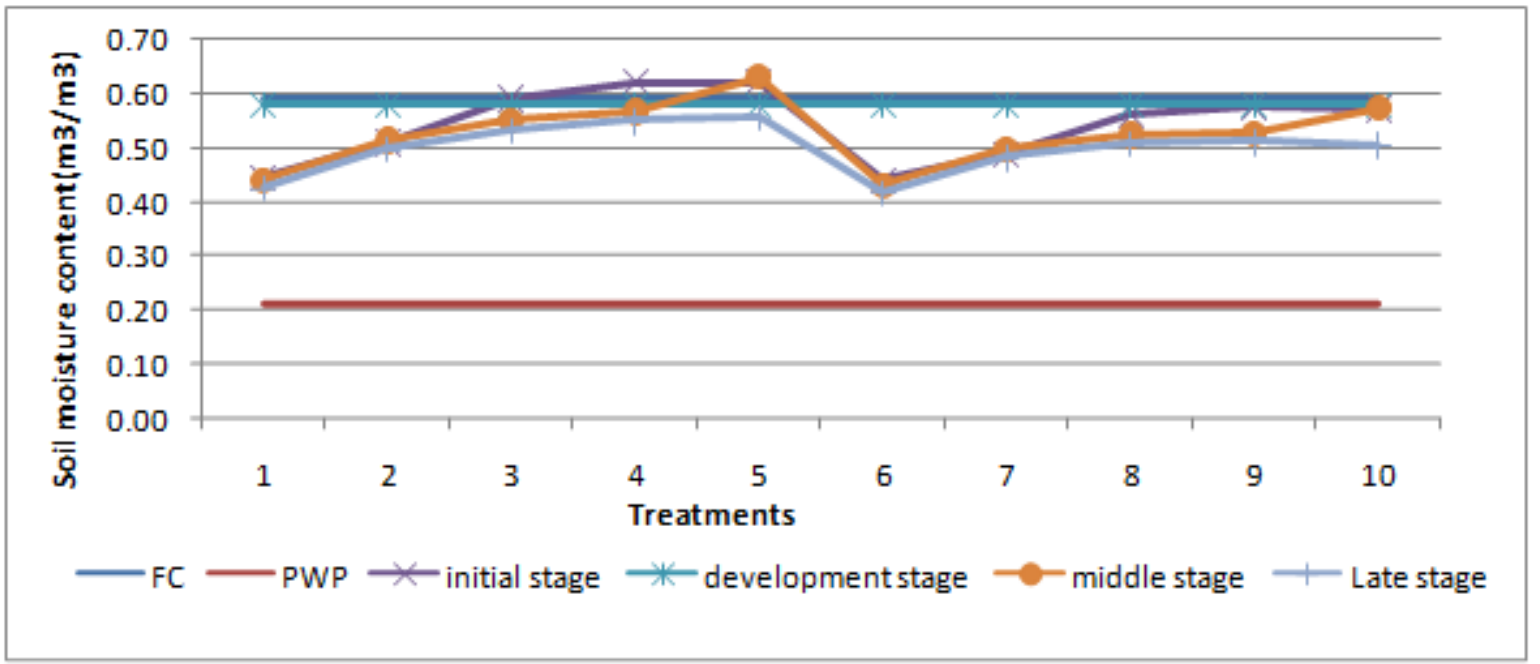

b)

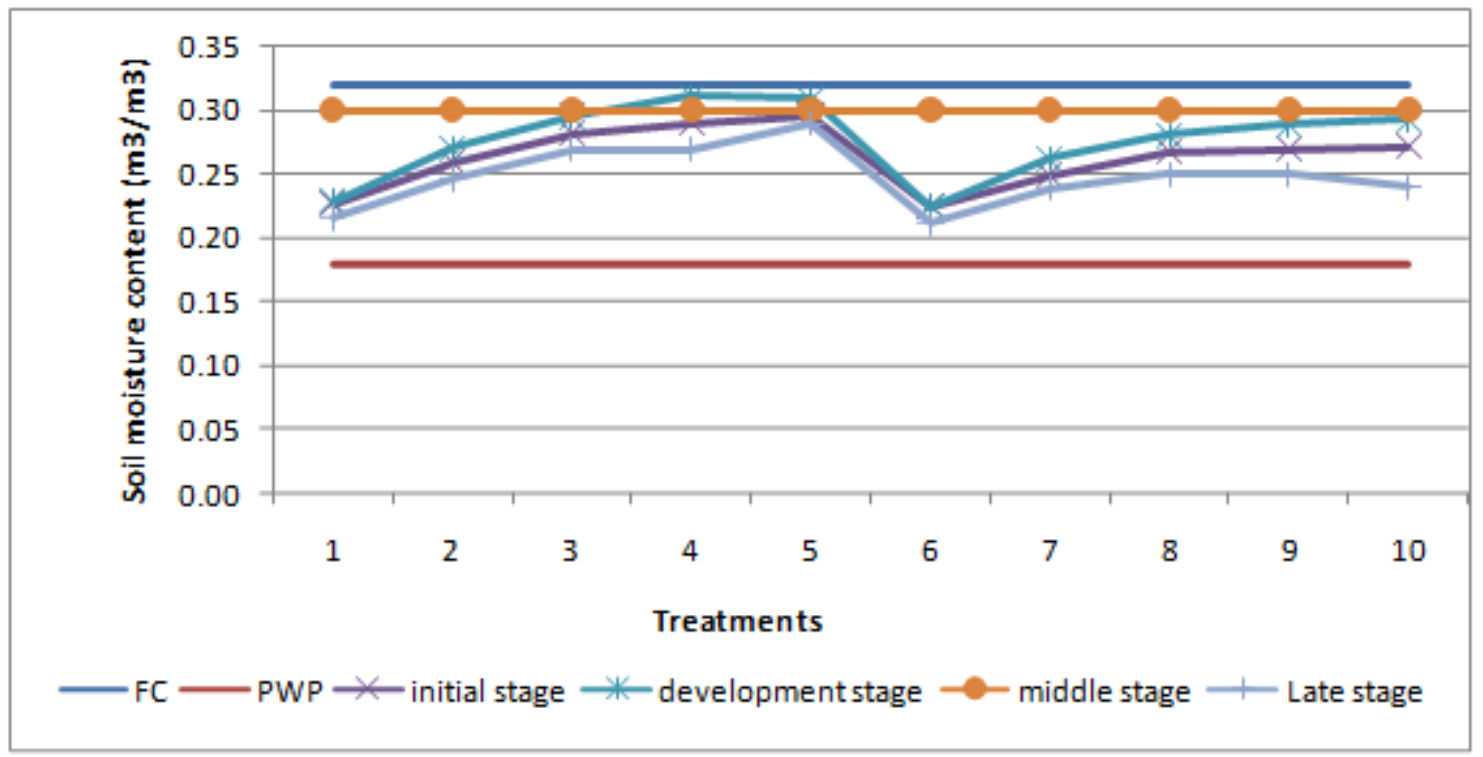

Figure 2

Average volumetric soil moisture content in four-crop growth stage vs irrigation regimes during 2016/17 experimental season a) Ribb irrigation scheme b) Koga irrigation scheme 